\title{
INTEGRATION OF ENVIRONMENTAL SAFEGUARDS INTO ETHIOPIAN INVESTMENT AND SECTORAL LAWS
}

\author{
Mohammed Ibrahim Ahmed*
}

\begin{abstract}
The aim of this article is to analyse the nature, scope and extent to which environmental norms and principles are integrated into the Ethiopian investment laws. The integration of an environmental matter into investment laws is very important in that it ensures that investment bodies and institutions do not disregard the environment by focusing only on economic achievement. The legal analysis of Ethiopian investment laws shows that although they contain environmental protection provisions, the language, manner and extent of stipulation adopted differ. The Mining Operation Proclamation No. 678/ 2010, Energy Proclamation No. 810/2013 and Petroleum and Petroleum Products Supply Operation Proclamation No. 838/2014 integrate environmental protection in an unequivocal manner. However, the Investment Proclamation No. 769/2012 and Transaction of Precious Minerals Proclamation No. 651/2009 do not use similar language with proceeding proclamations. This article argues that if environmental protection is integrated both under the Investment Proclamation No. 769/2012 and the Transaction of Precious Minerals Proclamation No.651/2009, the language used in both proclamations should be unequivocal, clear and in good manner similar to those of Mining Operation Proclamation No. 678/2010, Energy Proclamation No. 810/2013 and Petroleum and Petroleum Products Supply Operation Proclamation No. 838/2014.
\end{abstract}

Keywords: Investment and environment, economy and environment, environmental protection, sustainable development, environmental and investment issues.

DOI: https://dx.doi.org/10.4314/jsdlp.v8i2.6

* LL.B (ekelle University), LL.M (Jimma University), Lecturer at Law School of Ambo University, Ethiopia. Email:ibshi66@yahoo.com 


\section{INTRODUCTION}

One of the fundamental policy aims of virtually any country is to achieve development. Such desire is high in developing and least developed countries. However, development is a contentious and complex concept. The ways to realize development is also equally complex. Historically, economic growth was taken as central concept to development. ${ }^{1}$ Later, economic and social improvement for the majority became a central concept in the understanding of development. Economic development, with its social progress, came to occupy an essential place in theory and policy. ${ }^{2}$

However, such kind of development thinking that only focuses on economic and social forces creates many problems. ${ }^{3}$ It brings about negative impacts of development on the environment. Environmental issues have become crucial ifdevelopment is to be sustainable. Hence, the growing awareness of challenges to development thinking (that targeted only economic and social development) has led to the increasingly wide acceptance of a new concept - that of sustainable development. It means economic development that protects the environment and that brings economic development with its social progress. $^{4}$

As a result of the wide acceptance of this new concept, it is recognized that any policies and laws of a country that advocate development as its objective should take into account environmental protection. Investment is a primary driver of such growth. If environmental matters are not included in these laws, it may bringabout environmental disregard in the side of investment organ by making them to think that their main objective is to bring about economic growth only. This may make people toassociateenvironmental issueswith the concerns of the environmental groups only. Therefore, any investment policyor law of a country that embodies the development as its objective must take sustainable development into account.

The most frequently used definition of sustainable development is the one by the World Commission on Environment and Development

1 Jonathan M. Harris, Basic Principles of Sustainable Development (Tufts University, 2000) 1 .

2 Ibid.

3 Ibid.

4 ibid., 1-5. 
(hereinafter cited as WCED). It defines the concept as "development that meets the needs of the present without compromising the ability of future generations to meet their own needs". ${ }^{5}$ This definition embraces environmental protection, as well as social and economic development. It ties environmental, economic and social imperatives together. ${ }^{6}$

For the development to be sustainable, environmental protection is very important. And sustainability could be achieved through the effective balancing of social, environmental and economic objectives. ${ }^{7}$ Since the environment is the supplier of all things to the economy, if environmental damage is unchecked, it may undermine the achievements of development and even lead to the collapse of essential ecosystems. ${ }^{8}$ Similarly desperate poverty, weak or non-existent social safety nets and little concern for issues of equity and social justice bring about economic unsustainability. ${ }^{9}$ Therefore, integrated systems of environmental, social and economic management arecritical to making the required development sustainable. The historicalconcepts of development that exclude the environmental integration or protection in the development process have become unacceptable for various reasons. ${ }^{10}$

The purpose of this article is to examine whether Ethiopian investment laws have accommodated environmental aspects of

5 Colin C. Williams and Andrew C. Millington, "The Diverse and Contested Meanings of Sustainable Development" (2004)170 The Geographical Journal 99.

6 The Johannesburg Declaration on Sustainable Development(2002) Art.5.

7 Yosef Jabareen, "A New Conceptual Framework for Sustainable Development" <https://www.eqb.state.mn.us/.../EnvDevSust10p179ANewConceptualFra > accessed on 30 February 2015.

8 Harris (n1).

9 ibid 1-4.

10 There was a view which says economic development should take precedence over environmental concern. See Yosef, Jabareen(n 8). This view believes that people overcome environmental problem by substituted product and technological progress. See Williams and Millington (n 6) 101. This kind of thinking is undermined because human-made substituted product is not like a natural one and also there is some natural resource that cannot be substituted by human being once depleted, e.g. the Ozone layer. Economic growth and resource exploitation can continue. What is required is a better accommodation of environmental issues, with the extent to which they need to be accommodated. The logic of prior protection of environment is acceptable rather than later curing of the ill effect of economic growth. Ibid. 
sustainable development and also to evaluate how such accommodation is made, if it exists.There are many Ethiopian investment laws in operation but the widely used and applicable ones are the Investment Proclamation No. 769/2012 (as amended by Proc. No. 849/2014) with its regulation No. 270/2012, the Mining Operations Proclamation No. 678/2010, the Petroleum Operations Proclamation No. 838/2014, the Energy Proclamation No. 810/2013 and The Transaction of Precious Minerals Proclamation No. 651/2009. This article examines the nature, scope and content of environmental integration under these investment laws. The article demonstrates that although environmental protection is integrated both under the investment Proclamation No. 769/2012 and the Transaction of Precious Minerals Proclamation No. 651/2009, the language used in both proclamations must be unequivocal, clear and coherent just as the one used in the Mining Operations Proclamation No. 678/2010, and the Energy Proclamation No. 810/2013.

This article is divided into six sections. After this introduction, section 2 examines whether the declared objective of sustainability under the preamble of Investment Proclamation No. 769/2012 is included under its specific provision of the proclamation. Section 3 deals with the Mining Operations Proclamation No. 678/2010 while section 4 deals with the Transaction of Precious Minerals Proclamation No. 651/2009. Also, section 5 covers the Energy Proclamation No. $810 / 2013$, while section 6 deals extensively with the Petroleum and Petroleum Products Supply Operation Proclamation No. 838/2014. Section 7 contains the conclusion and recommendations.

\section{INTEGRATION OF ENVIRONMENTAL MATTER UNDER THE INVESTMENT PROCLAIMATION NO.769/2012}

The ultimate goal of investment is to accelerate the economic development of a country and improve the living standards of its people. ${ }^{11}$ Within the ambit of this overarching goal, the preamble also makes reference to other specific goals, such as encouraging and expanding investment, strengthening domestic production capacity,

11 Investment Proclamation No. 769/2012, Federal Negarit Gazeta of The Federal Democratic Republic of Ethiopia,18th Year No. 63, Addis Ababa,17th September, 2012. 
increasing the inflow of capital, and speeding up of transfer of technology.

The investment proclamation outlines the general as well as the specific objectives of investment in the context of Ethiopia. The general objective, as stated under Article 5 of the Proclamation, is "to improve the living standard of the peoples of Ethiopia through the realization of sustainable economic and social development," while the specific objectives include accelerating economic development, exploiting and developing the natural resources of the country, developing the domestic market, increasing foreign exchange earnings, encouraging balanced development, enhancing the role of the private sector in economic development, and creating ample employment opportunities.

The general objective of investment in Ethiopia is to realize sustainable economic and social development. However, the "sustainability" aspect of development that takes into account environmental concerns does not feature prominently in the specific objectives outlined under Article 5. As mentioned above, the inseparability of environment from economic and social development objectives is the central tenet of the concept of sustainable development. The specific objectives appear to capitalize on economic growth with some reference to social aspect but the sustainability aspect is not clearly articulated.

At any rate, whether or not the declared objective relating to sustainability has been translated into the specific provisions of the proclamation is an issue that requires further scrutiny of the provisions of the law because the non-inclusion of environmental matter in the specific objectives of the proclamation may not mean that the proclamation does not recognize the relevance of environmental protection to the attainment of its goals/objectives. This probably means the best way to achieve the sustainability aspect of sustainable development is not by including it in the specific objectives of the proclamation. This emanates from the objective part of the proclamation that does not impose any right or obligation.

It is useful only for the interpretation of the provision according to that objective but not when disputes arise from the application of the provision. The sustainability aspect of development is achievable by including it under a separate provision of the proclamation that imposes right and obligation. As a result, further examination of whether the proclamation provides for obligation of environmental protection to the attainment of its objective is crucial. We now proceed to a discussion of these. 
The most prominent provision of the proclamation on environmental concern is Article 38, which states as follows:

Any investor shall have the obligation to observe the laws of the country in carrying out his investment activities. In particular, he shall give due regard to environmental protection.

There are two possible interpretations regarding this provision. The first interpretation is that the word referring to the environment is formulated in a weak language. The first sentence does not add anything since it is the obligation of an investor to respect the laws of the country where he/she operates. Although the second sentence makes a direct reference to the environment, the way the sentence is constructed raises issues. Indeed, the way the obligation is formulated ("give due regard to environmental protection") appears to be weak. The sentence does not unequivocally state that an investor must respect the environmental laws of the country. Hence, Article 38 is nothing but a reminder for the investor to protect the environment without imposing legal obligation". ${ }^{12}$ Hence, according to this understanding, it can be concluded that the declared general objective under Article 5 relating to sustainability (environment) is not translated into this specific provision.

The second interpretation is that this provision attaches greater importance to environmental protection. Although it requires investors to observe all laws of the country, it particularly requires them to give due regard to environmental protection. Alternatively, investors can give due regard to environmental protection only if they observe the laws pertaining to environmental protection. At the moment, Ethiopia has many environmental protection laws. So, investors must observe any of these laws which they find to be applicable in the course of doing their business"13 Hence, according to this understanding, it can be said that environmental protections are given due regard and the declared general objective under Article 5 relating to sustainability (environment) has been translated into this specific provision.

Another way of understanding this concept is arguably more convincing for three reasons. First, the principle of legality in investment,

12 Fikremarkos Merso, "Green Growth, Investment, Environment and Sustainable Development in Ethiopia" 5 IUCNAEL EJournal, 163,169.

13 Dejene Girma, "The Chance to Improve the System of EIA in Ethiopia: A Look at the New Investment Proclamation" 3 Oromia Law Journal, 134,152. 
which means, in the absence of contrary obligation under bilateral investment treaties and international obligation, investors must act in accordance with the laws of host countries. So, the first sentence simply recognizes this principle. All laws that can be violated through investment such as human rights, labour laws, etc., are some of the laws envisaged by the first sentence along with environmental laws. Indeed, the second sentence singles out environmental laws because it is the law that is usually violated by investors.Environmental damage encompasses all; it destroys economic development obtained by investment itself, etc., and the proclamation brings this to the fore.

Second, looking at the value that the government gives to the environment through the enactment of various environmental laws before the enactment of this proclamation, one can interpret the idea or message under Article 38 as a provision to oblige investors to observe those various environmental lawsenacted before this proclamation. Most of the environmental policies, proclamations, regulations and directives were enacted before this proclamation. This proclamation is, therefore, the most recently introduced investment proclamation. Hence, looking at the various enactments of environmental laws, those before this proclamation showthe government prioritizingthe environment. One may understand this Article as the one that wants to oblige the investors to keep those various environmental laws before it.

Third, the message conveyed under Article 30(4)(d) supports the precedingassertion. Article 30(4)(d), requires the investment agency to execute investors requests for approval of impact assessment studies conducted in relation to their investment projects. This means that investors are not expected to go to the relevant environmental protection organs to have their environmental impact assessment (herein after cited as EIA) reviewed and approved. Instead, they can submit their EIA to the investment agency and the agency will pass over the report to the appropriate environmental organ for review and approval. Even if the Article does not compel investors to do EIA, it implies that investors are expected to do EIA when the activities they intend to carry out are subject to EIA according to the relevant instrument, which supports the obligation to respect environmental laws of the country under Article $38 .{ }^{14}$ It follows from these arguments

14 Girma (n 13) 152-153. 
that the message under Article 38 is equivalent to obliging the investors to respect the environmental laws of the country using the language investor must respect the environmental laws of the country.

Here, one may raise the question on the intent ofArticle 38 by saying, what is the purpose of observing environmental laws in the absence oflegal consequences? What if an investor fails to discharge his/her obligation under environmental laws? There is no consequence provided for by the investment Proclamation likewise. ${ }^{15}$ One answer to this question can be that since Article 38 is the general provision that is referring to various environmental laws of the country, the consequences of failure to protect those environmental laws are not as such mandatorily regulated by investment laws.

A different line of argument can be raised to support this assertion. First, since this investment proclamation is an economic law, it is not required to regulate or mention every aspect of environmental laws. Hence, for the purpose of integrating environmental matters, obliging environmental protection through environmental laws are enough. In other words, this is to mean imposing positive obligation through economic laws, for sanctions under the concerned laws are enough.

Second, environmental violations through investment activities are investment-related problems. But, it is not investment claim. Investment claim and environmental claims are two different things. Investment claims can only be made under investment laws and environmental claims only under environmental laws. This means that the forum for environmental claim should not be by investment organ. Hence, entertaining the legal consequence of not protecting the environment under environmental laws becomes logical.

Third, the proclamation does not leave the legal consequence of not protecting the environment entirely to environmental laws, since it provides the non-observance of environmental obligation such as environmental standard and EIA as one ground of suspension or revocation of license under Article 19(1) and (2)(a). This fact can be clarified as follows: As per the above understanding, Article 38 is a provision that obliges the investors to protect environmental laws. This means it is a provision under investment law that obliges the investors torecognize environmental protection under environmental laws. In conjunction with this Article, Article 19(1) says: "Where an investor violates the provisions of this Proclamation or regulations or

15 Merso (n 12). 
directives issued to implement this Proclamation, the appropriate investment organ may suspend the investment permit until the investor takes due corrective measures".

The combined reading of the two provisions reinforces the message that violation of environmental laws is considered a violation of Article 38 under this proclamation (because it obliges environmental law protection) that renders suspension of investment license according to Article 19(1).

Article 19(2)(a) also conveys the same message. Article 38 is a provision that obliges the investors to protect environmental laws. This means it is a provision under investment law that obliges the investors to environmental protection by law. For example, one of the obligations under the environmental laws is the submission of correct and appropriate EIA to the concerned organ(s). The investors are obliged to bring correct and true EIA that is devoid of false statement before environmental organs to obtain environmental permit. In the same manner, they are also obliged to bring the real and verified EIA by environmental organ before the investment organ to obtain investment permit.

In line with this fact, Article 19(2)(a) says: "The appropriate investment organ may revoke an investment permit where it ascertains that (a) the investor obtained the permit fraudulently or by submitting false information or statements". The combined reading of the two provisions (Art.38 and 19(2)(a)) means that the submission of a fraudulent or false EIA to either of the two organs to obtain the permits is considered a violation of environmental law under Article 38 that renders revocation of license according to Article 19(2)(a).

Another important point that relates to the above question is mentioned under Article 19(6). This article adds strength to the deterrent effect of article 19(2)(a). It stipulates that investors whose permits are revoked will not be issued new permits before the expiration of one year from the date of revocation. Hence, investors whose permits are revoked must wait until one year passes from the date their permits are cancelled to obtain new investment permits. On the other hand, this is not a risk that rational investors may want to take. In relation to environmental protection, this means that rational investors will abide by the requirements of the environmental laws so as to avoid the possibility of having their permits revoked. ${ }^{16}$

16 Girma (n13) 155. 
Besides the above question, one may again raise another question with regard to part four of the proclamation that deals with investment permits. Provision under part four (Article 12, 13, 14, 15, 16, 17 and 18) cover issues such as application, issuance, renewal and expansion or promotion investment permits. Among other things, they prescribe the conditions and requirements for issuance, renewal, application and expansion or promotion of investment permit. However, environmental conditions, such as compliance with environmental standards and the making of EIAs, are not provided as a requirement for application, issuance, renewal and expansion or promotion. Hence, how we can say this proclamation has protected the environment? ${ }^{17}$

The answer to this question is similar to the one to the earlier question. These provisions are concerned only with the investment requirement under investment law excluding environmental requirement under environmental laws. This means it is only concerned about the requirement that falls under investment claim. Environmental conditions, such as compliance with environmental standards and the making of EIAs, are not required to be mentioned here since environmental requirements and other environmental obligation are referred to environmental laws as per Article 38. However, this does not mean that investment organs have no legal obligation to require investors to produce environmental permits to obtain investment permits as per part four of the said provisions. As we have said above, Article 38 obliges the investors to protect environmental laws, which entail complying with EIAs and all necessary approval required by the environmental laws. Hence, since Article 38 is a provision under investment proclamation that obliges environmental protection.It is the obligation of the investment organ to know basic commitmentthat environmental protection laws entail and to enquire aboutsuch requirement before giving investment permit to investors as per part four of the said articles. This requires cooperative work between investment organs and environmental protection organs and also requires the deposit of some document by environmental protection organ with the investment organ.

Citing another provision from another proclamation, that is, Article 3(3) of EIA Proclamation No. 299/2002, can corroborate this obligation of investment organs. This provision obliges investment organs to ask

17 Merso (n 12) 168-169. 
the investors to produce environmental permits and all other necessary investment requirementsunder environmental laws from the environmental protection authority before receiving aninvestment permit as per part four of proclamation No. 769/2012. Obliging the investment organ through another proclamation does not produce any difference since both are proclamations enacted by theLegislaturewhich confers upon them equal status.

Furthermore, as mentioned hereinabove, making violation of environmental obligation under Article 38 as one ground of suspension/ revocation of license under Article 19, entails that an investment organ has the obligation to check environmental protection and obey environmental laws as a prerequisite for receivingan investment permit as per part four of the said provision, with the object to suspend/ revoke the license when they come across such violation.

From the above analysis, one may inferthe integration of environmental matters under this proclamation. This isclarifyingwhen compared to its predecessor Investment Proclamation No. 280/2002 as amended by Investment (Amendment) Proclamation No. 375/2003, which had no similar coverage to the environment.

In sum, investment proclamation No. 849/2014 that amends investment proclamation No.769/2012 does not come with a new idea on environmental protection, not mentioned under this proclamation. However, in defining the industrial development zoneit reaffirms the statement "... with the objective of mitigation of the impact of environmental pollution..." under Proclamation No. 769/2012 in defining the same that reflect the provision of due regard to the environmental protection. For this reason it does not deserve further argument.

Lastly, Regulation No. 270/2012 is enacted under proclamation No. 769/2012. Based on this regulation, one may also raise another question, namely, that regulation No. $270 / 2012$ provides area eligible for incentives between Article 5 and 15. However, these incentives are provided on the basis of factors such as export performance, sector (manufacturing, industry, information and communication technology, etc.) and the region where the investment takes place. Environmental prerequisite does not appear to be a justification for an incentive. Hence, how we can say proclamation No. $769 / 2012$ has protected the environment? The answer to this question can be provided as follows.

It is better if the incentives are also provided on the basis of environmental prerequisite to encourage environmental protection 
under this regulation. However, since the environmental protections are mentioned under proclamation No. 769/2012 as obligation of investor, the failure to provide incentive for one's own obligation under the law does not make the regulation defectiveas such. This follows sincemost of the time incentives are not provided to discharge one's own obligation under the laws. It is mostly provided in the absence of an obligation. Hence, since it is the obligation of the investors and their investment to protect the environment and to operate in an environmentally friendly manner, there is no need to provide incentive as of obligation for environmental protection to which the consequence of failure to fulfil this obligation brings about suspension, revocation, etc., of investment permit.

\section{MINING OPERATIONS PROCLAMATION NO. $678 / 2010$}

This proclamation is the one that clearly stipulates environmental matters. This proclamation includes environmental matters under its goal, starting from the preamble: "it is the obligation of the Government to protect the environment for the benefit of present and future generations and to ensure ecologically sustainable development of minerals". This is similar to the expression used in the WCED report. Also, one of the objectives of the proclamation, as stated under Article 4(5), is "to ensure that the country's mineral resources are developed in an orderly and sustainable manner", which means in a way that meets the need of the present and future generations.

Article 60(1) of this proclamation obliges any applicant for a license to submit an EIA and all the necessary approvals from a competent authority required by the relevant environmental laws of the country (except in case of reconnaissance license, retention license or artisanal mining license). Similarly, according to Article 18(1)(c), a mineral exploration license can only be granted, inter alia, if the environmental impact plan submitted by the applicant has been approved. The same is true for the grant of a license for a large-scale mining license under Article 26(1)(c), as well as a small-scale mining license under Article 28 (1)(c). One of the grounds for the suspension and revocation of a mineral license under Article 44(2)(e) of the proclamation is if the licensee is in breach of the approved EIA.

Even if the artisanal mining operators have no obligation to submit EIA and any other requirement under environmental laws as per Article 
60(1), Article 32(2) (a) obliges the holder of an artisanal mining license to undertake the mining operations in accordance with the environmental protection standards prescribed for artisanal mining which shows the care given to environmental protection under this proclamation. In addition to other specific obligations provided to each mining license holder under the proclamation, Article 34(1)(a) and (b) oblige all licensee to carry out mining operations in compliance with the applicable laws pertaining to environmental protection. Under part five in determining the powers and duties of the licensing authority, Article 52(4)(j) states that "any licensing authority shall have the powers and duties toensure that mining operations carried out by licensees take into account the environment". It conveys the message that obliges the authorities to follow up the activity of the licensee to check whether he/she is operating according to the environmental laws.

Article 62(1) of the proclamation also states that"in the event the holder of a license is deceased, cannot be traced, or in the case a company ceases to exist or has been liquidated, the Licensing Authority may take the necessary measures to prevent further pollution or to make the area safe". This is what is done to protect the environment from damage. Finally, under Article 78, the proclamation provides for the penalty for any person who contravenes or fails to comply with any provision of theseproclamation, regulations, directives or the terms and conditions of a license that include environmental obligation.

Article 60(2) obliges all licensees except the holder of reconnaissance, retention or artisanal licensee to allocate funds to cover the costs of rehabilitation of environmental impact. This may be prior to or post impact allocation of fund to rehabilitate the environment. The idea under this provision shows the care given to the environment.

Looking at all the above environmental focused provisions under this proclamation, one can say that the Mining Operations Proclamation No. 678/2010 clearly and unequivocally coversenvironmental matters. Moreover, this proclamation puts legal obligation on investment organ under Article 60(1) to require investors to produce EIA and all necessary approvals required by environmental laws from competent authority to obtain investment permit. This implies that the investment organ has the obligation to verify the environmental protection practices of the investors during renewal and expansion or improvement of investment permit in addition to verification during issuance. 


\section{TRANSACTION OF PRECIOUS MINERALS PROCLAMATION NO.651/2009}

Regarding part two of the proclamation that covers issues such as application, issuance, renewal and revocation of license, one may say that it rightly prescribes the conditions and requirements for the issuance, renewal, application and revocation of license.However, it does not provide for environmental conditions as a requirement for the application, issuance, renewal and revocation of license. The exception to this stipulation is Article 13(2) (c) which says, "where the application is for Crafting License, the application shall contain business plan including waste management". In so doing, the Proclamation has failed to make the connection between environmental protection obligations and the content of license permits by making environmental considerations a precondition for the grant of a permit, or the failure to observe the environmental laws of the country a possible ground for the revocation of a permit.

Nevertheless, this proclamation provides the consequences of failure to observe environmental obligations under part three of Article 28(2)(b). As provided under this Article, licensees who violate environmental protection operating standards under different environmental laws of Ethiopia are punishable with a fine of 30,000 birr and an imprisonment of seven years. The penalty imposed under this provision conveys the message that obliges the investor to operate according to dictates of the environmental laws. In conjunction with this idea, Article 17(1) says, the license is renewed only when the licensee is not in breach of his obligation under this proclamation. When these provisions are read together with Article 28(2) (a), it gives the meaning that the violation of environmental obligation under environmental laws are considered as the violation of one's obligation under Article 28(2)(b) of this proclamation that deserve punishment with a fine of 30,000 birr and an imprisonment of seven years together with the refusal of license renewal under Article 17(1). Also Article 21(1)(e) says, the license is revocable when the person contravenes the obligation under this proclamation. As it is envisaged under Article 28(2) (b), one of the obligations of the licensee is to produce in line with their obligation under environmental laws. This means that violations of the obligation under environmental laws are considered as violation of the obligation under Article 28(2)(b) that deserves the revocation of license as per Article 21(1)(e). 
Similarly, Article 21(1)(e) provides for the revocation of an operating license if the licenseefails to fulfil their obligations under this proclamation. As it is provided under Article 21(1)(a), one of the obligations for the licensee under this proclamation is the submission of correct and appropriate EIA documents to the concerned organ to obtain a license. The combined reading of the two provisions, that is, Art. 21(1)(a) and Art. 21(1)(e), shows that the submission of fraudulent or false EIA to obtain the permit is considered a violation of one's obligation under Article 21(1)(a) and is punishableby the revocation of the operational license according to Article 21(1)(e).

Finally, from Article 28(2)(b), it is understood that it is illogical to think that a personthat is punished with a fine of 30,000 birr and an imprisonment of seven years mightnot have his license revoked and suspended. From what has been discussed under this topic, it can be understood that this proclamation integrates environmental mattersthat precede the proclamations even if not couched in similar language. The manner of stipulating a licensee's obligations and punishment in case of a default under this proclamation is more inclined to the stipulation under proclamation No. 769/2012.

\section{ENERGY PROCLAMATION NO. 810/2013}

This proclamation contains different environment-related provisions similar to mining operations proclamation No. 678/2010. The core provision of the proclamation that relates to environmental matters is analysed as follows. Article 6(2) of the proclamation says, "Any person desiring to generate, transmit or distribute electricity for non-commercial purposes shall notify the authorities in advance and produce documents evidencing that he has fulfilled environmental protection and safety conditions". This article obliges the person who has the desire to engage in electricity-related activities for non-commercial purpose to produce evidence to the Ethiopian Energy Authority (hereinafter calledthe Authority) showing that he has fulfilled environmental protection and safety conditions. In other words, before getting the license the investors are obliged to produce evidence showing that they have fulfilled environmental protection conditions (that is EIA). Hence, this article puts as a precondition, the prior approval of EIA from the concerned authorities to get an operational license to generate power.

Article 7 contains the idea that the license is issued to a person only where the person has fulfilled the requirement for the license 
under other investment laws and environmental laws and where the Ethiopian Energy Authority is satisfied with that. As is known, different Ethiopian investment laws and environmental laws stipulate varied environmental protection requirements to get investment licenses. Some of those requirements have been mentioned above. For this reason, according to this Article, before an applicant can get an investment license in the energy sector, such a person is required by law to fulfil environmental requirements under this proclamation as well as other investment laws and the environmental laws, and the Authority has to be satisfied with the fulfilment of those requirements.

In conjunction with this, article 6(3) obliges all persons who engage in activities related toenergy prior to the coming into force of this proclamation, to submit their applications to the authorities along with other necessary particulars in order to obtain a license. As earlier mentioned, one of the necessary particularsthat is as a precondition for getting the license under article 7 is the fulfilment of environmental protection requirement under other investment laws and environmental laws. Hence, according to this article, even the licenses of those who had been engaging in energy-related activities prior to the coming into force of this proclamation areby obligation required to renew their licensesafter showing particulars of environmental protection requirements to the authorities.

Beside this stipulation, the proclamation under article 10(2) provides that, "Any licensee shall carry out his activities in compliance with this Proclamation, regulations and directives issued hereunder and in the relevant environmental protection laws, and safety, quality and performance standards determined by the Authority". This Article obliges the licensees to conduct their activities through due observance of environmental protection in line with their obligations under the environmental laws. From this, it is understood that a violation of environmental obligation under environmental laws can be considered a violation of obligation under this proclamation.

In conjunction with this provision, Article 4(2) and 8(2) stipulates the conditions for the revocation or suspension of a license and certificate of competence in the case of violation of obligations under this proclamation. The same Article also stipulates the penalties to be imposed in terms of money and/or term of imprisonment in the case of violation to the obligation under this proclamation. In other words, whoever violates the obligations prescribed under the environmental lawswouldtheir license revoked/suspended and further penalized by a 
fine and/or imprisonment since it is considered a violation of this proclamation.

Article 15(2) says: "No electrical installation may be energized from the supply line of the licensee without being certified for safety compliance by licensed electrical inspector". This means any wiring, equipment, fittings and other materials used or intended to be used to convey electricity beyond the point of supply to the point of consumption is required to satisfy the safety condition and has to be certified for that by licensed electrical inspectors before connecting it to the supply line of the licensee. Such safety requirement is a precaution intended to protect people and the environment from damage that may arise from the poor handling of electricitysupply.

Another thing is Article 29(1) that says: "Any person who presents a false or misleading statement to the Authority in relation to any information required under this Proclamation shall be punished with simple imprisonment up to five years or with a fine of up to Birr 25,000 or with both". As we noted above, one of the preconditions to get a license in the energy sector is the prior submission of environmental protection requirements from the environmental and investment authorities, and the submission of these documents to the authorities for approval. Hence, according to this article, a person is required to provide correct, accurate and true information to the authorities about environmental requirements from the approving body. In other words, if a person provides false and misleading information about environmental requirement, he may be punished with simple imprisonment of up to five years or with a fine of up to Birr 25,000 or with both in addition to the revocation and suspension of the license.

Looking at the environmental provisions under this proclamation, it can be said that this proclamation stipulates environmental conditions that are similar to those of the Mining Operation Proclamation No. 678/2010. Similarly, this proclamation imposes on the would-be investor in electricity the obligations ofobtaining the appropriate environmental compliance documents from the concerned authorities and the submission of the same to the approving bodies in order to get the license under article 7 . This implies that the Authority granting the license has the obligation to verify the fulfilment of environmental requirement from the concerned organ before issuing the license to a person. It also promises the revocation and suspension of the license in addition to a penalty in terms of a fine and imprisonment for those who have violated their environmental 
obligation under this proclamation, investment and environmental laws.

\section{PETROLEUM AND PETROLEUM PRODUCTS SUPPLY OPERATION PROCLAMATION NO. 838/2014}

Under its preamble this proclamation stipulates that "it is essential to ensure that the petroleum and petroleum product supply operation carried out in the country comply with accepted international safety and quality standards to safeguard human health, property and theenvironment". This means that petroleum products shall be produced in compliance with internationally accepted environmental standards in order that the environment may suffice to meet the present and future generation needs. Article 5(1) obliges any person who wants to engage in petroleum supply operations to apply for a certificate of competence to the Ministry of Water, Irrigation and Energy (hereinafter called the Ministry). In addition to this, Article 6(2)(d) obliges the Ministry to take into consideration the impact it may cause on the environment before issuing certificates of competence.

Furthermore Article 6(3) confines the power on the Ministry to refuse the application if it has good reason to think that the operation may cause harm tothe environment. This means thatthe Ministry requires approved EIA, because if the Ministry is supplied with correct EIA, there is no need to take into consideration its impact on the environment and to refuse the application. In corroboration of this provision, Article 18 says: "the ministry, in consultation with the appropriate body, shall define petroleum supply operations that require environmental impact assessment by directive to be issued for the implementation of this proclamation as a precondition for issuing certificate of competence pursuant to this proclamation". Hence if petroleum supply operation is a type of operation that requires EIA under the directive, the licensee is required to submit the correct assessment where the Ministry is obliged to confirm and forthwith issue the certificate of competence for licensees.

However, for a kind of petroleum supply operation that needs no EIA under the directive, the Ministry is obliged to take into consideration the impact it may cause on the environment before issuing a certificate of competence and refuse if it has good reasons to think that the operation may cause harm tothe environment. As far as I know, there is no directive issued in this regard. However, I think that a type of 
petroleum products that arenot subject to EIA do not constitute the kindsubject to Federal Government Permit as mentioned under EIA directive.

Moreover, Article 10(1) talks about the suspension and revocation of certificate of license if licensees violate any of their obligations under the laws concerning environmental protection. As it is known, Ethiopia has different environmental laws with different obligationsintended to safeguard the environment. Hence, according to this article, in order to continue with the supply of petroleum operation (without their license being suspended or revoked), the licensees are required to observe their entire obligation under the various environmental laws of the country.

Furthermore, Article 16(1) obliges the licensee to comply with the entire obligations under the environmental laws concerned with environmental protection during the supply of petroleum products. In line with this stringent obligation, Article 10(1) also talks about the suspension and revocation of licenses if there is any violation ofthe obligation under this proclamation. When these two provisions are examined together, it is equal to sayingthat the violation of any environmental obligation under environmental laws against the obligation under Article 16(1), is considered a violation of one's obligation under this proclamation according to article 10 (1), that deserves suspension and revocation of license.

Article 19(1) says: "where there is more than 500 litres of petroleum products spill[ed], the custodian of the product shall report the incident to the ministry or to the organ delegated by the ministry within 24 hours after the incident". This is intended to protect the environment from disruption that may occur as a result of petroleum spill over the environment. Hence, according to this proclamation, the guardian of the petroleum is obliged to inform the Ministry where more than 500 litres of petroleum products spill into the environment in order to enable the Ministry to take appropriate measures to protect the environment. This can be more understood from the provision of the same Articles which says: "the custodian or the owner of the product shall immediately take appropriate measures to clean up the spill to prevent the occurrence of any damage to the environment".

In determining the power and duty of the Ministry, Article 25(4) says: "the ministry shall have powers and duties to evaluate and approve applications submitted pursuant to this proclamation in consultation with pertinent bodies to maintain public health and safety and 
environmental protection and ensure safety supply chain operation". It is mentioned here that for the kind of petroleum supply operation that requires EIA, the applicants are obliged to bring correct EIAs. Similarly, it is mentioned that for the kind of petroleum supply operation that needs no EIA, the Ministry is obliged to take into consideration its impact on the environment before issuing the license. When Article 25(4) is considered in conjunction with this provision, it means that the Ministry has the obligation to consult with concerned environmental authorities about the possible impact on the environment before issuing a license even for the type of petroleum supply operation that does not require the conduct of EIA.

Sub-section eight of the same Article obliges the Ministry to undertake necessary monitoring and inspection activities on petroleum supply operations in relation to its impact on the environment. This Article obliges the Ministry to conduct monitoring and inspection before and after providing the licensee with license. This fact can be elaborated as follows. If it is a kind of operation that needs EIA, the Ministry needs to check whether the licensees have brought the correctEIA before issuing the licenses. If it is a kind of operation that does not need EIA, the Ministry in consultation with environmental authorities, need to examine the possible impact on the environment before issuing the license. After taking all these control measures, the Ministry still needs to monitorwhether the licensees comply with the terms of his license approval or not. During the inspection, if the Ministry come across a licensee thatdoes not operate according to the terms of the approval, it revokes or suspends the license as per Article 10(1).

Finally, the proclamation says under article (33): "any person who has engaged in petroleum products supply chain before the effective date of this proclamation shall make the necessary arrangements with respect to his petroleum facility and its practices to comply with the provision of this proclamation and regulations and directives to be issued for the implementation of this proclamation within the time limits determined by the ministry".

The working document prior to thisenactment was the amended petroleum operation proclamation No. 295/1986. This amended proclamation does not provide environmental obligations similar to the newly enacted one. For example, this proclamation compels making the conduct of EIA (with the obligation to operate accordingly) and operation in line with all environmental laws required. It also promises the revocation and suspension of licenses for those who do not fulfil 
their obligations. There is no such stringent obligation under the amended proclamation. Hence, those who have been working under the amended proclamation are obliged to comply with all environmental obligations under this proclamation if they do not want their licenses revoked or suspended. This means they are required to conduct EIA and operate according to the obligations under the existing environmental laws; otherwise their license will be revoked or suspended as per this proclamation.

From what has been discussed so far, one can see that this proclamation has so many provisions related to environmental protection similar to the Mining Operation Proclamation No. 678/2010 and Energy Proclamation No. 810/2013. It also contains different environmental protection provisions compared to the amended petroleum operation proclamation No. 295/1986 as it provides statutes that are not stipulated under the amended proclamation. Among other things, it obliges the production of petroleum in accordance with the accepted environmental standard.It also requires, as a precondition, the submission of EIA to get a license.Furthermore, it provides the conditions for the revocation and suspension of licenses for violating one's obligation under the environmental laws.It furtherobliges those who have a license before the enactment of this proclamation to renew their license in line with the environmental requirement under this proclamation.

\section{CONCLUSION AND RECOMMENDATION}

As demonstrated in this article, Ethiopian investment laws have integrated environmental protection matters. However, a number of gaps appear in the integration approaches adopted in these instruments, which have limited their overall efficacy.

First, proclamation No. 769/2012 integrated environmental protection by obliging investors to protect environmental laws under Article 38. Through this obligation it also committedinvestment organs to require environmental permitsas a prerequisite for investment permits. It also made the violation of any obligation under Article 38 as a violation of this proclamation under Article 19 that renders revocation or suspension of investment license. Furthermore, by providing revocation or termination of a license under Article 19 for non-compliance with environmental obligation under Article 38, it affirms the responsibility of investment organ to check/verify 
environmental obligation observance during issuance, renewal etc. of license under part four of the remaining Articles. From the analysis, it is understood that this proclamation provides environmental law protection provisions. This is better understood when compared to its predecessor, the Investment Proclamation No. 280/2002 as amended by Investment (Amendment) Proclamation No. 375/2003 that has no similar coverage to the environment.

Second, regulation No. 270/2012, which provides the area of investment eligible for incentives, is totally devoid of environmental consideration. To provide incentives, the regulation is only based on criteria such as export performance, sector and the region where the investment takes place while it does not take into account the environmental prerequisite. This is the reasonwhy environmental protection is made obligatory through observance of environmental laws that donot requireincentives to discharge one's own obligation under the laws.

Third, the Mining Operation Proclamation No. 678/2010, Energy Proclamation No. 810/2013 and Petroleum and Petroleum Products Supply Operation Proclamation No. 838/2014 integrate environmental protection in unequivocal and clear manner. Among other things, they stipulate anobligation to produce the EIA as a precondition for getting a license, they oblige the observance of environmental laws during the operation, and they provide suspension and revocation of license for the violations of one's obligation under environmental laws. Furthermore, the Mining Operation Proclamation No. 678/2010 and Energy Proclamation No. 810/2013, provide penalty in terms of fine and imprisonment in addition to revocation and suspension of license.

Fourth, Transaction of Precious Minerals Proclamation No. 651/ 2009 provides the penalty for the violation of environmental protection operating standards under different environmental laws of the country through Article 28(2)(b). This penalty compels mineral production according to set environmental laws. It makes the violation of obligation under environmental laws as the violation of this proclamation under Article 21(1)(e) that deserves revocation of license. It also makes violation of this obligation as one ground to refuse the renewal of license under Article 17(1). From the analysis that is made under this section, it is understood that this proclamation provides environmental laws protection provisions.

The problem of inadequate integration of environmental safeguards in Ethiopian investment laws can be addressed through a holistic law 
reform process. For example, the Provision under part four of proclamation No. 769/2012 covers issues such as application, issuance, renewal, expansion or promotion. However, environmental conditions such as compliance with environmental standards and making EIA are not provided in explicit language as a requirement for application, issuance, renewal, expansion or promotion of investment permit even if it can be understood through interpretation of Article 38 and 19 of the same proclamation in conjunction with Article 3(3) of EIA Proclamation No. 299/2002. Hence, in order to avoid possible understanding and to have better protection of the environment, environmental compliance should have to be added as a requirement for application, issuance, renewal, expansion or promotion of investment permits.

Moreover, in order to give more effective implementation for the environmental protection, the proclamation should contain clear language regarding cooperative working between investment and environmental organs, which include the obligation to require investors to produce environmental permits to obtain investment permits by investment organ.

Similarly, Transactions of Precious Minerals Proclamation No. 651/ 2009 aims to punish licensees who violate environmental protection operating standards under different environmental laws of Ethiopia with fine of 30,000 birr and an imprisonment of seven years. However, it does not provide environmental condition as a requirement for application, issuance, renewal and revocation of license in explicit language even if it can be understood through interpretation of different provisions of the proclamation. In order to avoid ambiguity and to have better protection of the environment, it is better to state in an unequivocal manner environmental protection as a pre-requisite for application, issuance, renewal and revocation of license. In order to give more effective implementation to environmental protection, the proclamation should contain in clear language coordination between the Ministry of Mines and Energy or licensing authority and environmental organ, which includes the obligation to require persons to produce environmental permits to obtain work permits by Ministry/ licensing authorities. 